\title{
CORROSION RESISTANCE OF LASER-DEPOSITED COMPOSITE COPPER-BASALT OVERLAY
}

\author{
${ }^{1}$ Pavla KLUFOVÁ, ${ }^{1} J a n$ TITTEL, ${ }^{2}$ Marek VOSTŘÁK, ${ }^{2} Z$ deněk JANSA, ${ }^{1}$ Antonín KŘíž \\ ${ }^{1}$ Department of Material Science and Technology, Faculty of Mechanical Engineering, University of West \\ Bohemia, Czech Republic,EU, klufovap@fst.zcu.cz, tittejan@rti.zcu.cz, kriz@kmm.zcu.cz \\ ${ }^{2}$ New Technologies - Research Centre, University of West Bohemia, Czech Republic, EU, \\ mvostrak@ntc.zcu.cz, zjansa@ntc.zcu.cz
}

https://doi.org/10.37904/metal.2019.877

\begin{abstract}
This paper deals with an assessment of the corrosion resistance of copper-basalt composite cladded by laser. The filler powder for laser overlaying was a mixture of high-purity copper powder Oerlikon METCO 55 consisting of $45-90 \mu \mathrm{m}$ particles and a basalt powder comprising particles $50-250 \mu \mathrm{m}$ in size. Under this experimental programme, three series of specimens were prepared (5 wt. \% basalt; $10 \mathrm{wt}$ \% basalt; and $15 \mathrm{wt}$ \% basalt). The substrate was C45 steel $20 \mathrm{~mm}$ in thickness. The corrosion resistance of the laser clads was assessed by potentiodynamic corrosion testing using the linear polarization method. The electrolyte was an synthetic prepared mine water. Metallographic evaluation of the laser clads was carried out using optical microscopy (OM) and scanning electron microscopy (SEM). Based on the outcomes of this study, a summary was developed of the application potential of the laser-deposited composite copper-basalt overlay for surface treatment of storage containers for underground spent nuclear fuel repositories located in the Czech Republic.
\end{abstract}

Keywords: Laser cladding, copper-basalt composite, potentiodynamic corrosion test, X-ray diffraction

\section{INTRODUCTION}

Laser cladding relies on the high-energy-density laser beam to melt the base material as well as the cladding material. The latter may be in the form of powder or wire. The cladding process produces a narrow region, in which the melted cladding material and base material become metallurgically bonded. Their solidification thus leads to strong metallurgical bonds which provide the deposit with good cohesion as well as adhesion to the base material. The goal of laser cladding is to create a weld clad with desired properties and chemical composition on the base material without extensive dilution (>10\%) between the two metals [1].

Laser cladding applications in the power generation and nuclear industries are not new. The first documented mention dates back to 1981 when a protective weld clad was deposited by laser on the joints between turbine blades and rotor in the Rolls Royce company [2].

Among them, there is the unique concept of composite laser weld cladding for protection of outer surfaces of storage containers for spent nuclear fuel in underground repositories. In the Czech Republic, the fundamental requirements on storage containers have been set out by the State Office for Nuclear Safety (SÚJB). They include an extremely high corrosion resistance of the outer surface. The SÚJB stipulates that storage containers should retain their corrosion resistance for at least 100,000 years in the underground repository environment. The composite material for the corrosion-resistant outer layer of storage containers for spent nuclear fuel is based on materials and constituents that have existed on Earth since time immemorial. Degradation processes in chemically-pure metals (such as copper) and igneous rocks can be assessed reliably in order to obtain corrosion resistance predictions for the 100,000-year period defined by the SÚJB. 


\section{EXPERIMENTS}

The purpose of the experimental programme was to contribute to development of a composite laser weld clad/base material with high corrosion resistance in a defined environment. The base material was ČSN EN 10083-2 (C45) steel sheet of $20 \mathrm{~mm}$ thickness ground on both sides. The chemical composition of C45 steel is shown in Table 1.

Table 1 Chemical composition of C45 steel (base material), element content in weight per cent [3]

\begin{tabular}{|c|c|c|c|c|c|c|c|}
\hline $\mathbf{C}$ & $\mathbf{S i}$ & $\mathbf{M n}$ & $\mathbf{C r}$ & Mo & $\mathbf{N i}$ & $\mathbf{P}$ & $\mathbf{S}$ \\
\hline $0.40-0.52$ & 0.43 & $0.46-0.84$ & 0.45 & 0.13 & 0.45 & 0.04 & 0.04 \\
\hline
\end{tabular}

A special laser cladding material was created by mixing high-purity copper powder and basalt. The copper powder was purchased from Oerlikon Metco under brand name Metco 55. Basic information on powder particle sizes, specifications and properties of Metco 55 powder are given in Table 2.

The basalt powder for this experimental programme was purchased in a store which sells materials for hand work and model building. The powder grain size was measured using SEM; and was found to be $45-250 \mu \mathrm{m}$. It was also examined using X-ray diffraction. The diffractogram of the basalt powder is shown in Figure 1. Phases identified in the powder are listed in Table 3.

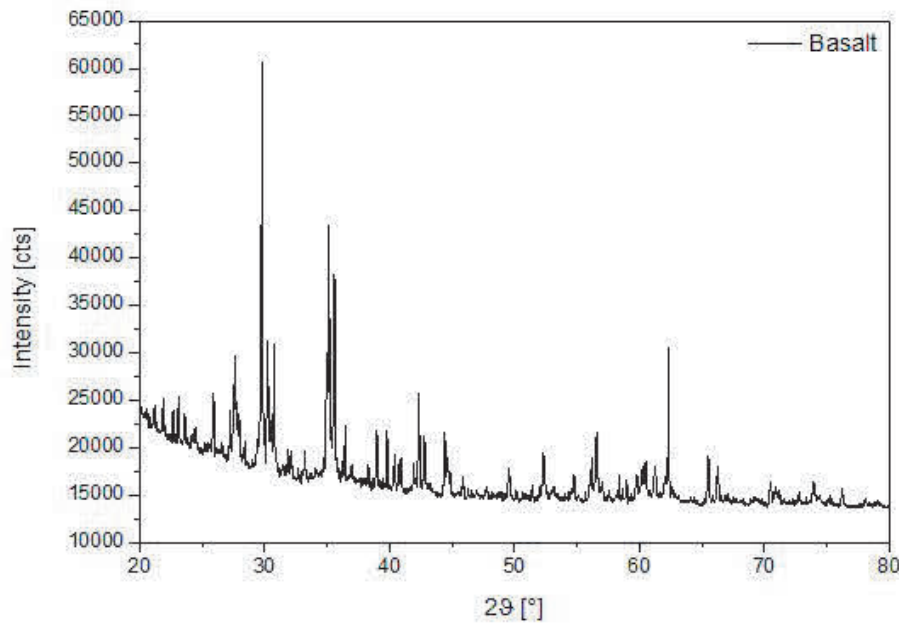

Figure 1 Basalt powder, diffractogram

Table 2 Metco 55 powder, specifications and properties declared by the manufacturer [4]

\begin{tabular}{|c|c|c|c|c|}
\hline Copper content & Powder particle size & Morphology & Melting point & Density \\
\hline Cu min. $99 \%$ & $45-90 \mu \mathrm{m}$ & Spherical & $1,356 \mathrm{~K}\left(1,083^{\circ} \mathrm{C}\right)$ & $8,960 \mathrm{~kg} / \mathrm{m} 3$ \\
\hline
\end{tabular}

Table 3 Phase composition of the basalt powder found by X-ray diffraction

\begin{tabular}{|c|c|c|c|c|c|}
\hline No. & Compound name & Chemical formula & No. & Compound name & Chemical formula \\
\hline 1 & Magnesium oxide & $\mathrm{MgO}$ & 11 & Cristobalite II & Si8.0016.0 \\
\hline 2 & Periclase $(a=0.4200)$ & Mg4.004.0 & 12 & Calcium Aluminium Oxide & Ca5.0Al6.0014.0 \\
\hline 3 & Periclase $(a=0.3952)$ & Mg4.004.0 & 13 & Calcium-magnesium silicide & Ca4.0Si4.0Mg4.0 \\
\hline 4 & Quartz $(a=0.4702, c=0.5256)$ & Si6.006.0 & 14 & Alite & Ca54.0Si18.0090.0 \\
\hline 5 & Quartz $(a=0.4973, c=0.5267)$ & Si6.006.0 & 15 & Pyroxene ideal & Mg8.0Si8.0024.0 \\
\hline 6 & Quartz $(a=0.4722, c=0.5267)$ & Si6.006.0 & 16 & Sillimanite & Al8.0Si4.0020.0 \\
\hline 7 & Silicon Oxide (Orthorombic) & $\mathrm{SiO} 2$ & 17 & Enstatite & Mg16.0Si16.0O48.0 \\
\hline 8 & Silicon Oxide (Hexagonal) & $\mathrm{SiO} 2$ & 18 & Tobermorite & Ca5.0Si6.0018.0 \\
\hline 9 & Titanite & Ca4.0Si8.0O20.0 & 19 & Mullite & Al4.8Si1.2O9.6 \\
\hline 10 & Cristobalite & Si8.0016.0 & 20 & Forsterit & $\mathrm{Mg} 2 \mathrm{SiO} 4$ \\
\hline
\end{tabular}

Laser cladding was carried out at New Technologies Research Centre (NTC) at the University of West Bohemia. Solid-state disc laser Trumpf TruDisk 8002 was used. Its wavelength was $\lambda=1,030 \mathrm{~nm}$ and the spot 
size was $3.4 \mathrm{~mm}$. Weld cladding powder was supplied via powder feeder GTV PF 2/2 MH to coaxial-feeding cladding head Precitec YC52 with a four-beam nozzle. The assist and shielding gas was 99.99 \%-purity argon.

Using laser cladding, three samples of composite copper-basalt overlays were prepared. A special mixture of laser cladding powder Metco 55 and basalt powder was prepared for each sample:

- $\quad$ SAMPLE A (95 wt.\% Metco 55, 5 wt. \% basalt powder)

- $\quad$ SAMPLE B (90 wt. \% Metco 55, 10 wt. \% basalt powder)

- $\quad$ SAMPLE C (85 wt. \% Metco 55, 15 wt. \% basalt powder)

The substrate was C45 steel. Each overlay had an area of $60 \times 95 \mathrm{~mm}$.

\section{METALLOGRAPHY}

The laser overlays were examined using metallographic techniques and Carl Zeiss Z1M optical microscope (OM) with Axiovision software, and Philips XL 30 ESEM microscope with an EDX analyser (SEM). Their microstructures were revealed using a chemical mixture available under the name Robin. The interface between the laser overlay and the base material was etched with $3 \%$ nital.

In the course of metallographic preparation of ' $95 \% \mathrm{Cu}, 5 \%$ metal oxides' specimen, the adhesion of the composite laser clad to the base material proved insufficient; and the clad separated from the substrate. For this reason, ' $95 \% \mathrm{Cu}, 5 \%$ metal oxides' samples were disqualified from subsequent examinations.

Figure 2 is a micrograph of the laser overlay on SAMPLE B (the cladding powder contained $90 \mathrm{wt}$ \% of Metco 55 and $10 \mathrm{wt}$. \% basalt). The matrix of the laser overlay consists of copper. The grain size of the copper matrix identified according to ČSN EN ISO 643 was G11. There is a dispersion of mostly round basalt particles in the matrix of the composite laser overlay.

Figure 3 shows an unmelted basalt particle at the fusion boundary of the laser overlay and the substrate in SAMPLE B. The hypothesis that it was an unmelted basalt particle was confirmed by EDX analysis (the point identified as EDX - M1 in Figure 3; the chemical composition is given in Table 4).

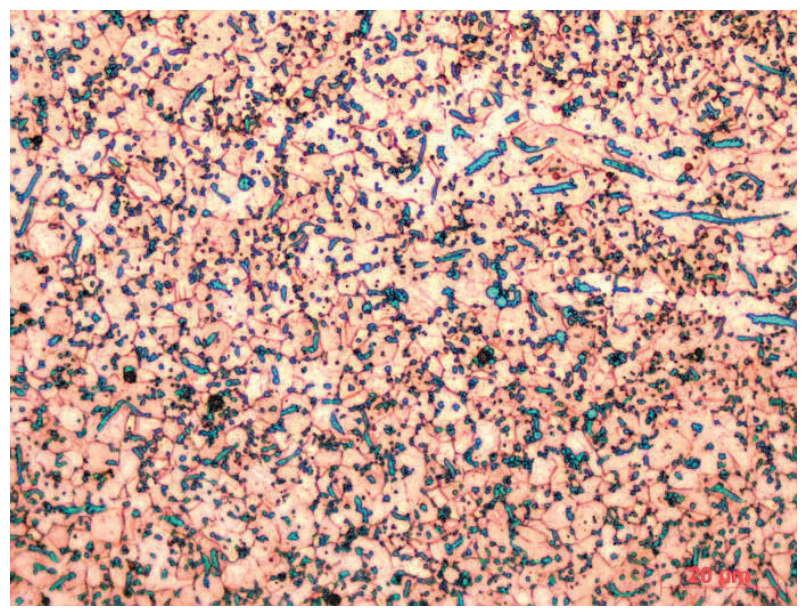

Figure 2 SAMPLE B; Cu-based matrix with a dispersion of basalt particles; etched with Robin reagent; magnification $1,000 \times$

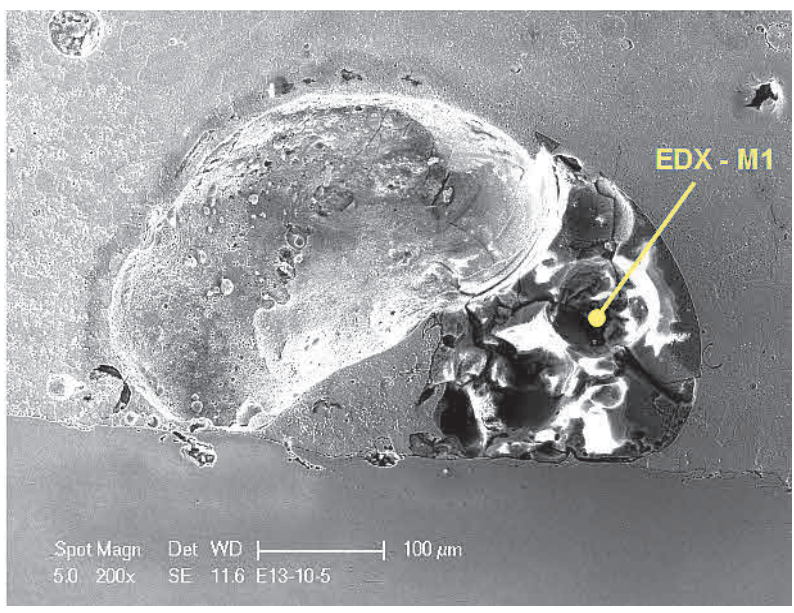

Figure 3 SAMPLE B; unmelted basalt particles; the region of EDX analysis of chemical composition is identified; SE image; magnification 200x

Metallographic examination of SAMPLEs A, B and C revealed severe heterogeneity of the laser-deposited composite overlays. The Cu-based matrix of the overlay contained some areas with dispersion of basalt particles. As the laser cladding process progressed, the overlay became increasingly contaminated with iron 
and other elements from the base material. Essentially, the joint between the composite copper-basalt overlay and the base material, a carbon steel, is a dissimilar weld. The fusion boundary is a problematic region, as it develops cracks during welding, which run into both the base material and the overlay. From the perspective of real-world use of laser-deposited copper-basalt composite overlays in highly-corrosive environments, the cracks in the overlay are a major weakness.

Table 4 Basalt; EDX analysis of chemical composition, element content in weight per cent

\begin{tabular}{|c|c|c|c|c|c|c|c|c|c|c|c|}
\hline & $\mathbf{F e}$ & $\mathbf{C u}$ & $\mathbf{S i}$ & $\mathbf{M n}$ & $\mathbf{N i}$ & $\mathbf{T i}$ & $\mathbf{C r}$ & $\mathbf{C a}$ & $\mathbf{A l}$ & $\mathbf{M g}$ & $\mathbf{0}$ \\
\hline EDX - M1 & 14.1 & 11.2 & 13.5 & 0.3 & 0.3 & 1 & 0.3 & 5.4 & 13.1 & 6.1 & 34.7 \\
\hline
\end{tabular}

\section{POTENTIODYNAMIC CORROSION TEST}

Corrosion resistance of the composite laser overlays was assessed using potentiodynamic corrosion testing with the aid of BioLogic SP-150 potentiostat. EcLab 10.44 software was employed for data processing and evaluation. First, the time dependence was measured of the steady-state corrosion potential between WE WORKING ELECTRODE and RE - REFERENCE ELECTRODE. The time for stabilization of free corrosion potential was identical in all measurements $t_{R}=30 \mathrm{~min}$. Linear polarization was used for finding the dependence of corrosion current (converted to current density) on the mixed corrosion potential of the sample within the range from $E_{i}$ to $E_{L}\left(\mathrm{E}_{\mathrm{i}}=\mathrm{E}_{\mathrm{corr}}-0.025[\mathrm{~V}] ; \mathrm{E}_{\mathrm{i}}=\mathrm{E}_{\mathrm{corr}}+0.025[\mathrm{~V}]\right)$ with respect to the reference electrode $(R E)$. The Tafel lines obtained were extrapolated using software EcLab 10.44 and the polarisation resistance $R_{p}[\mathrm{mV}]$ and corrosion rate $v_{\text {corr }}[\mu \mathrm{m} / \mathrm{year}]$ were determined [1]. The reference electrode ("RE") was a calomel electrode and the counterelectrode ("CE") was a $0.3 \mathrm{~mm}$ diameter platinum wire, which supplied electric current to the corrosion cell to induce voltage changes between the specimen and the calomel electrode [1]. The electrolyte was a pH 3.5 artificial mine water. Its chemical composition and method of preparation are described in [5]. The $\mathrm{pH}$ value was determined using a litmus paper. The conditions of potentiodynamic corrosion testing are summarized in Table 5.

Table 5 Potentiodynamic corrosion test - measurement conditions

\begin{tabular}{|c|c|}
\hline Potentiodynamic corrosion test conditions & Quantitative values \\
\hline Time for stabilization of free corrosion potential tR & $30 \mathrm{~min}$ \\
\hline Corrosion potential measurement range (E Range) & $-2 ; 2 \mathrm{~V}$ \\
\hline Ewe working electrode potential recording vs. time (de/dt) & $0.166 \mathrm{mV} . \mathrm{s}-1$ \\
\hline Linear polarisation within the range $(\Delta \mathrm{E})$ & $\pm 0.025 \mathrm{~V}$ \\
\hline Specimen area $(\mathrm{S})$ & $177 \mathrm{~mm} 2 ; 28 \mathrm{~mm} 2$ \\
\hline Density of Copper & 8.96 g.cm3 \\
\hline Equivalent weight of Inconel 625 & 32 g.eq-1 \\
\hline
\end{tabular}

As the composite copper-basalt laser overlays were considerably heterogeneous in terms of both chemical composition and structure, two types of corrosion cells were used for measuring their corrosion resistance. The first corrosion cell (designated below as $\mathrm{C} 1$ ) with an area of $177 \mathrm{~mm}^{2}$ was supplied by the manufacturer of the potentiostat. The other corrosion cell (identified as C2) with an area of $28 \mathrm{~mm}^{2}$ was specially designed for testing corrosion resistance of laser overlays, and 3D-printed in Felix 3.0 machine. The motivation for making the second cell for corrosion testing much smaller was to capture the heterogeneity of the composite laser overlays and measure and demonstrate it using the impedance method. Prior to corrosion resistance measurement, the laser overlays were ground in a magnetic grinding machine to their final thickness.

SAMPLE A was not included in the measurement because its overlay had shown poor adhesion to the base material. Potentiodynamic corrosion testing involved three measurements on each corrosion cells $\mathrm{C} 1, \mathrm{C} 2$ on 
laser clad SAMPLES B, C. One measurement on a copper sheet of $99.98 \%$ purity was used as the reference standard for comparing the measured and calculated corrosion rates. The corrosion rates obtained were converted to corrosion rates over a 100,000-year period (as stipulated by the SÚJB), assuming linear loss of laser clad and copper sheet with time. Data from the potentiodynamic corrosion test are summarized in Table 6.

Table 6 Potentiodynamic corrosion test; measured and calculated steady-state corrosion potential, polarisation resistance and corrosion rate

\begin{tabular}{|c|c|c|c|c|c|c|c|}
\hline $\begin{array}{l}\text { Designation } \\
\text { of sample }\end{array}$ & $\begin{array}{c}\text { Corrosion } \\
\text { cell }\end{array}$ & $\begin{array}{c}\text { Number of } \\
\text { measurements }\end{array}$ & $\begin{array}{c}\text { Corrosion } \\
\text { potential } \\
\text { Ecorr }[\mathrm{mV} \\
\text { vs RE] }\end{array}$ & 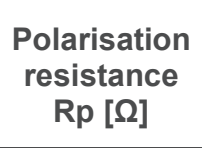 & 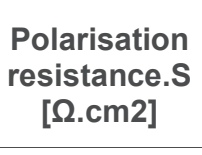 & $\begin{array}{l}\text { Corrosion } \\
\text { rate } \\
{[\mu \mathrm{m} / \mathrm{year}]}\end{array}$ & $\begin{array}{c}\text { Corrosion rate } \\
\text { over } \\
100000 \text { years } \\
{[\mathrm{mm}]}\end{array}$ \\
\hline Cu sheet & $\mathrm{C} 1$ & 1 & -175 & 6,334 & 11,211 & 0.023 & 2 \\
\hline \multirow{6}{*}{ SAMPLE B } & $\mathrm{C} 1$ & 1 & -352 & 82,499 & 146,023 & 0.284 & 28.4 \\
\hline & $\mathrm{C} 1$ & 2 & -402 & 79,541 & 140,788 & 0.332 & 33.2 \\
\hline & $\mathrm{C} 1$ & 3 & -505 & 76,917 & 136,143 & 0.442 & 44.2 \\
\hline & $\mathrm{C} 2$ & 1 & -288 & 223,337 & 63,204 & 0.743 & 74.3 \\
\hline & $\mathrm{C} 2$ & 2 & -505 & $5,070,000$ & $1,434,810$ & 0.041 & 4.1 \\
\hline & $\mathrm{C} 2$ & 3 & -484 & 104,34 & 29,529 & 1.899 & 189.9 \\
\hline \multirow{6}{*}{ SAMPLE C } & $\mathrm{C} 1$ & 1 & -491 & $9,270,000$ & $16,407,900$ & 0.003 & 0.3 \\
\hline & $\mathrm{C} 1$ & 2 & -535 & $8,120,000$ & $14,372,400$ & 0.003 & 0.3 \\
\hline & $\mathrm{C} 1$ & 3 & -510 & $9,870,000$ & $17,469,900$ & 0.003 & 0.3 \\
\hline & $\mathrm{C} 2$ & 1 & -512 & 9,042 & 2,559 & 14.741 & $1,474.1$ \\
\hline & $\mathrm{C} 2$ & 2 & -517 & 12,412 & 3,513 & 13.37 & $1,333.7$ \\
\hline & $\mathrm{C} 2$ & 3 & -324 & 26,479 & 7,494 & 7.45 & 794.5 \\
\hline
\end{tabular}

The last column in Table 6 contains converted corrosion rate measurements for a copper sheet and SAMPLEs $\mathrm{B}$ and $\mathrm{C}$. The corrosion loss in a copper sheet submerged in an electrolyte of artificial mine water was found to be $2 \mathrm{~mm} / 100,000$ years.

In SAMPLE B, the corrosion loss of the laser overlay was 4.1-189.9 mm/100,000 years, depending on the type of the corrosion cell used. In SAMPLE C, the corrosion loss of the laser overlay measured in C1 cell was $0.3 \mathrm{~mm} / 100,000$ let. However, SAMPLE C exhibited completely different levels of corrosion loss of its laser overlay when tested using corrosion cell $\mathrm{C} 2$ and the potentiodynamic method. The discrepancy between the corrosion losses in laser overlays in SAMPLE B and SAMPLE C suggests that they are very heterogeneous in terms of local chemistry and structure. The considerable discrepancies between the corrosion rate values are an indication of cracks in the laser overlays. In the potentiodynamic corrosion test, these cracks are manifested by an extreme local rise in the corrosion rate.

\section{CONCLUSION}

This paper deals with an assessment of the corrosion resistance of laser-deposited composite copper-basalt overlays. The substrate was C45 steel of $20 \mathrm{~mm}$ thickness. In this experimental programme, three laserdeposited composite overlays were prepared. Each of them had a different basalt content in copper-based Metco 55 laser cladding powder. The overlay which consisted of $5 \mathrm{wt}$ \% basalt and $95 \mathrm{wt}$ \% copper was disqualified from the experiments owing to poor adhesion of the overlay to the base material. The corrosion rates in SAMPLE B (10 wt. \% basalt and $90 \mathrm{wt}$. $\% \mathrm{Cu}$ ) and SAMPLE C ( $15 \mathrm{wt}$ \% basalt and $85 \mathrm{wt} . \% \mathrm{Cu})$ were 
determined by the potentiodynamic corrosion test. The electrolyte was an artificially-prepared mine water. Corrosion resistance was measured in two corrosion cells of different types. The C2 type was specially designed and 3D-printed for corrosion resistance testing of laser overlays. The lowest corrosion loss was found in SAMPLE C: $0.3 \mathrm{~mm} / 100,000$ years. Although the measured and converted corrosion losses for SAMPLE C and for the environment were extremely low, metallographic examination identified local cracks in the laserdeposited composite overlays. The application potential of laser-deposited composite copper-basalt overlays is now difficult to determine with certainty because research into preparation of laser overlays is still under way.

\section{ACKNOWLEDGEMENTS}

The authors gratefully acknowledge the funding for these tests provided under the applied research project of the Technology Agency of the Czech Republic ZETA TJ01000316. The above investigation was also funded by the Ministry of Education under the project LQ1603 entitled "Výzkum pro

SUSEN". The work was carried out in a large infrastructure designated as "Udržitelná energetika (SUSEN)" which had been built under project CZ.1.05/2.1.00/03.0108.

\section{REFERENCES}

[1] KLUFOVÁ, Pavla. Odolnost proti degradaci laserem navařených austenitických vrstev. Disertační práce. Západočeská univerzita v PIzni. Plzeň 2018.

[2] HEMATTI, Ismail. Laser-deposited metallic coatings, Ph.D. Thesis, Zernike Institute 2017.

[3] BOHDAN BOLZANO, s.r.o. Nelegované konstrukční oceli. C45 steel [viewed 2019-05-02]. Avaiable from https://www.bolzano.czl.

[4] Oerliko Metco. Datasheet - Metco 55. [viewed 2019-04-27]. Avaiable from https://www.oerlikon.com/

[5] TITTEL, Jan. Testování korozní odolnosti kompozitních laserem navařených materiálů s vysokým poločasem rozpadu. Diplomová práce. Západočeská univerzita v Plzni. Plzeň 2019. 